\title{
Tools make tools: changes in bone and antler manufacture at Late Bronze and Early Iron Age Polish sites
}

Justyna Baron ${ }^{1, *} \&$ Marcin Diakowski ${ }^{1}$

Analyses of worked faunal remains from three Bronze to Iron Age (c. 900-400 BC) sites in Poland demonstrate changing trends in Central European prehistoric hard-tissue-processing tools and techniques.

\section{Introduction}

This paper presents changing trends in tool selection for animal hard-tissue processing, evidenced at prehistoric settlement sites in south-western Poland. We focused on traces of production-observed on artefacts from well-dated contexts-to compare how they changed over time. We intended to test if the introduction of bronze into everyday life significantly influenced the working of bone and antler. To achieve this, we selected a collection of worked bone and antler pieces from three Polish sites dating from the Late Bronze Age to the Early Iron Age (roughly 900-400 BC) (Figure 1).

\section{The sites}

\section{Grzybiany}

At this site, three phases of occupation were identified, covering a period from the ninth/eighth century to the end of the fifth century BC. The faunal assemblage numbered over 11000 pieces, of which only 75 were worked. These comprised half-finished products, waste and finished objects (Baron et al. 2016).

\section{Wojkowice}

Wojkowice was excavated in 1998-2000, preceding construction of a motorway (Gralak 2010). Pits dated to the Late Bronze Age and the Early Iron Age produced 54 worked pieces of bone and antler, including half-finished products, waste and completed objects.

\section{Rusko}

In 1993, two rectangular structures made of pinewood were discovered at this partly destroyed site (Lasak 1995). The structures, both dated to the Early Iron Age, have no 


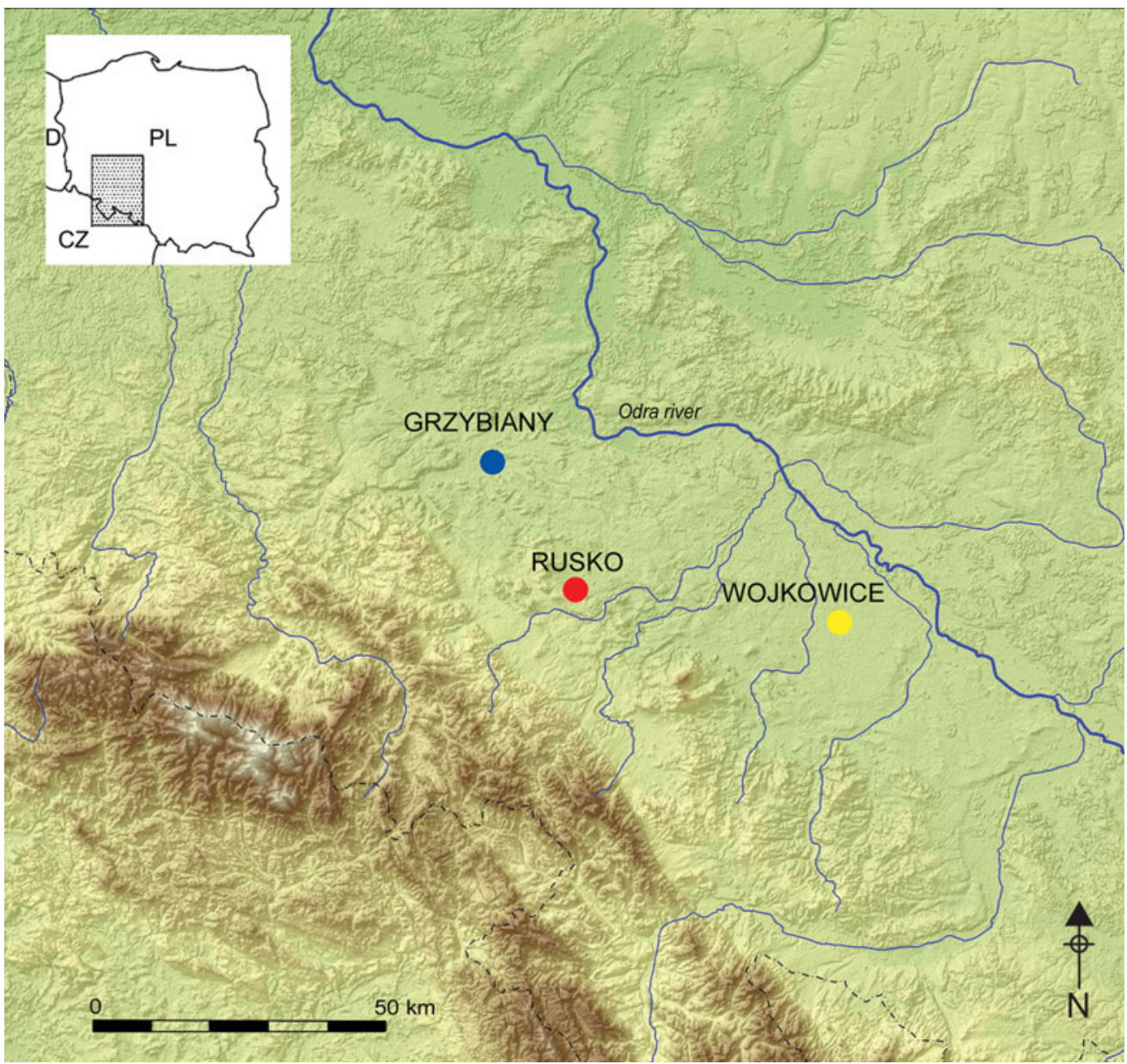

Figure 1. Locations presented in the paper.

\begin{tabular}{|c|c|c|c|c|c|}
\hline \multicolumn{2}{|c|}{ GRZYBIANY } & \multicolumn{2}{|c|}{ RUSKO } & \multicolumn{2}{|c|}{ WOJKOWICE } \\
\hline stone & metal & stone & metal & stone & metal \\
\hline $\begin{array}{l}\text { - pebbles } \\
\text { - wedges } \\
\text { - grinstones } \\
\text { - fint blades/flakes }\end{array}$ & $\begin{array}{l}\text { - axes/adzes } \\
\text { - knifes } \\
\text { - saws } \\
\text { - chisels } \\
\text { - rims }\end{array}$ & $\begin{array}{l}\text { - pebbles } \\
\text { - wedges }\end{array}$ & $\begin{array}{l}\text {-axes/adzes } \\
\text { - -knifes } \\
\text { - saws }\end{array}$ & $\begin{array}{l}\text { - pebbles } \\
\text {-wedges } \\
\text { - grindstones } \\
\text {-fint bladesifflakes }\end{array}$ & $\begin{array}{l}\text { - axesladzes } \\
\text { - knifes } \\
\text { - saws }\end{array}$ \\
\hline $\begin{array}{l}\text { - breaking } \\
\text { - flexion breaking } \\
\text { - knapping } \\
\text { - spliting } \\
\text { - grinding } \\
\text { - scraping } \\
\text { - grooving }\end{array}$ & $\begin{array}{l}\text {-chopping } \\
\text { - sawing } \\
\text {-scraping } \\
\text {-chiselling } \\
\text { - whittling } \\
\text { - ornamentation by grooving } \\
\text { - boring }\end{array}$ & $\begin{array}{l}\text { - breaking } \\
\text { - flexion breaking } \\
\text { - spliting }\end{array}$ & $\begin{array}{l}\text { - chopping } \\
\text { - sawing } \\
\text { - whitling }\end{array}$ & $\begin{array}{l}\text { - breaking } \\
\text { - flexion breaking } \\
\text { - knapping } \\
\text { - spliting } \\
\text { - grinding } \\
\text { - scraping } \\
\text { - grooving }\end{array}$ & $\begin{array}{l}\text { - chopping } \\
\text { - sawing } \\
\text { - scraping } \\
\text { - chiselling } \\
\text { - whitting } \\
\text { - boring }\end{array}$ \\
\hline
\end{tabular}

Figure 2. Tools and techniques identified through artefact analyses.

(C) Antiquity Publications Ltd, 2018 
Tools make tools

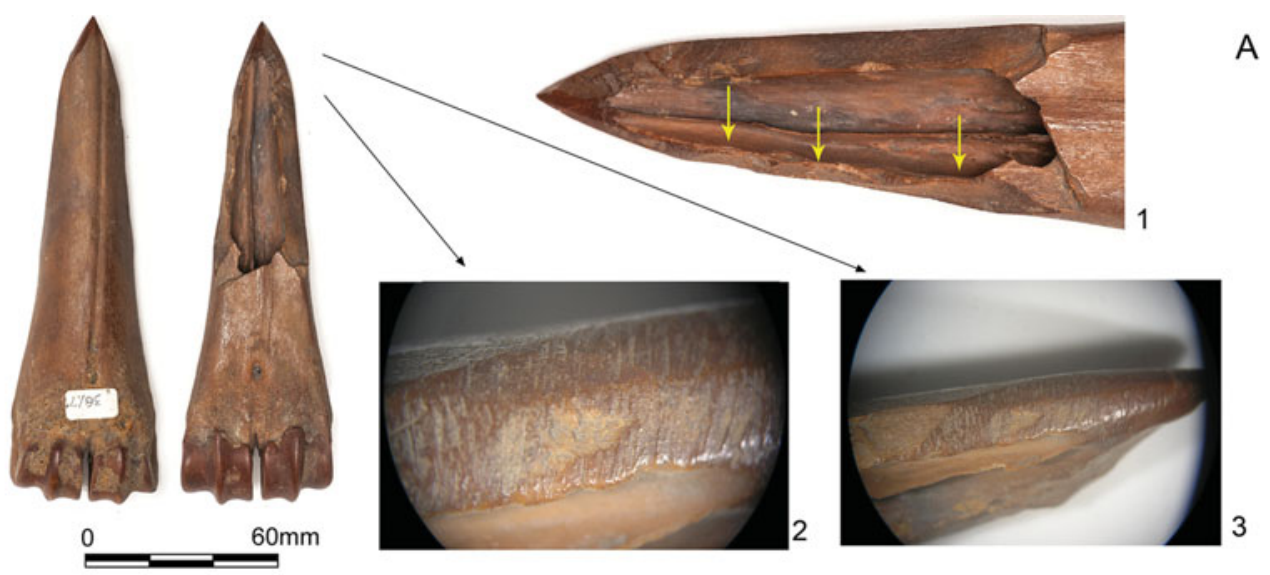

苞

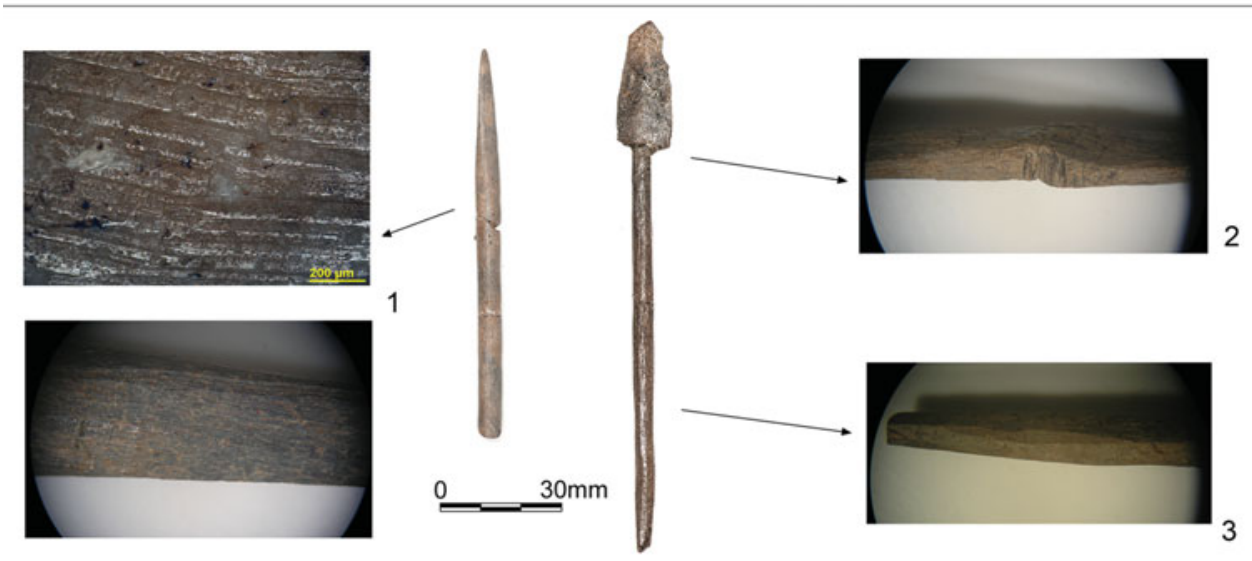

B

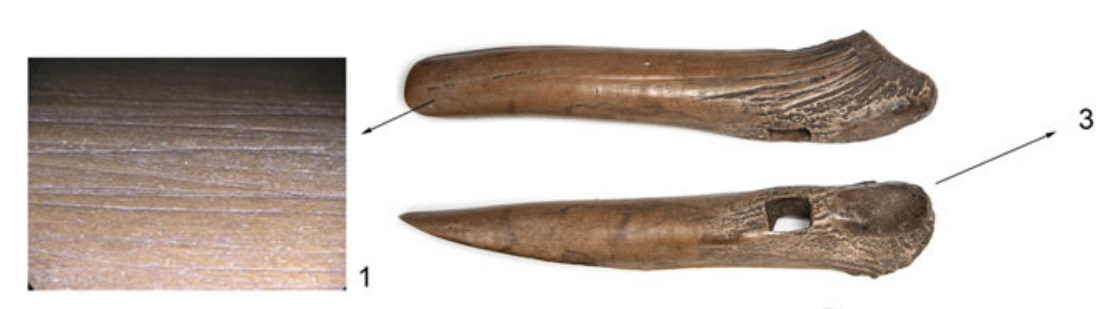

C
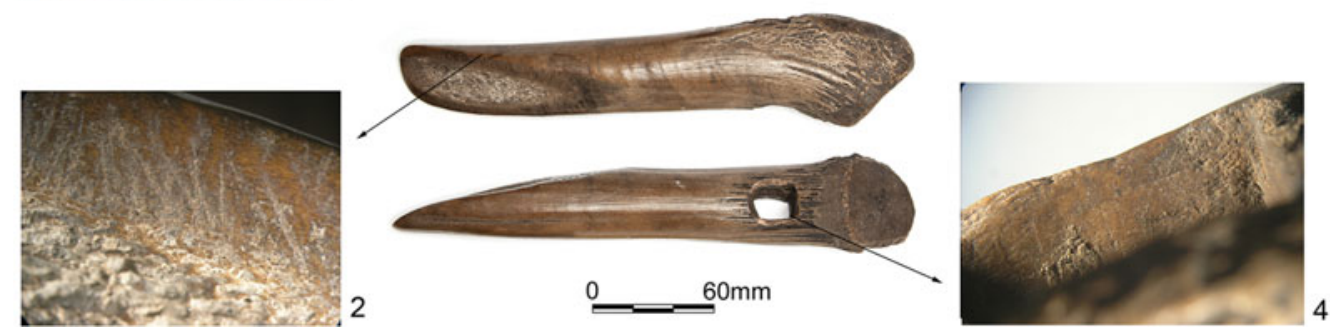

Figure 3. Tools and techniques, Grzybiany assemblage: A) one awl (only stone tools used): 1) knapping, 2-3) grinding; B) bone point and arrowhead (metal): 1) scraping, 2) sawing, 3) whittling; C) antler axe (stone and metal): 1) scraping (stone), 2) grinding (stone), 3) chopping (metal), 4) whittling (metal). All photographs by M. Diakowski.

(C) Antiquity Publications Ltd, 2018 

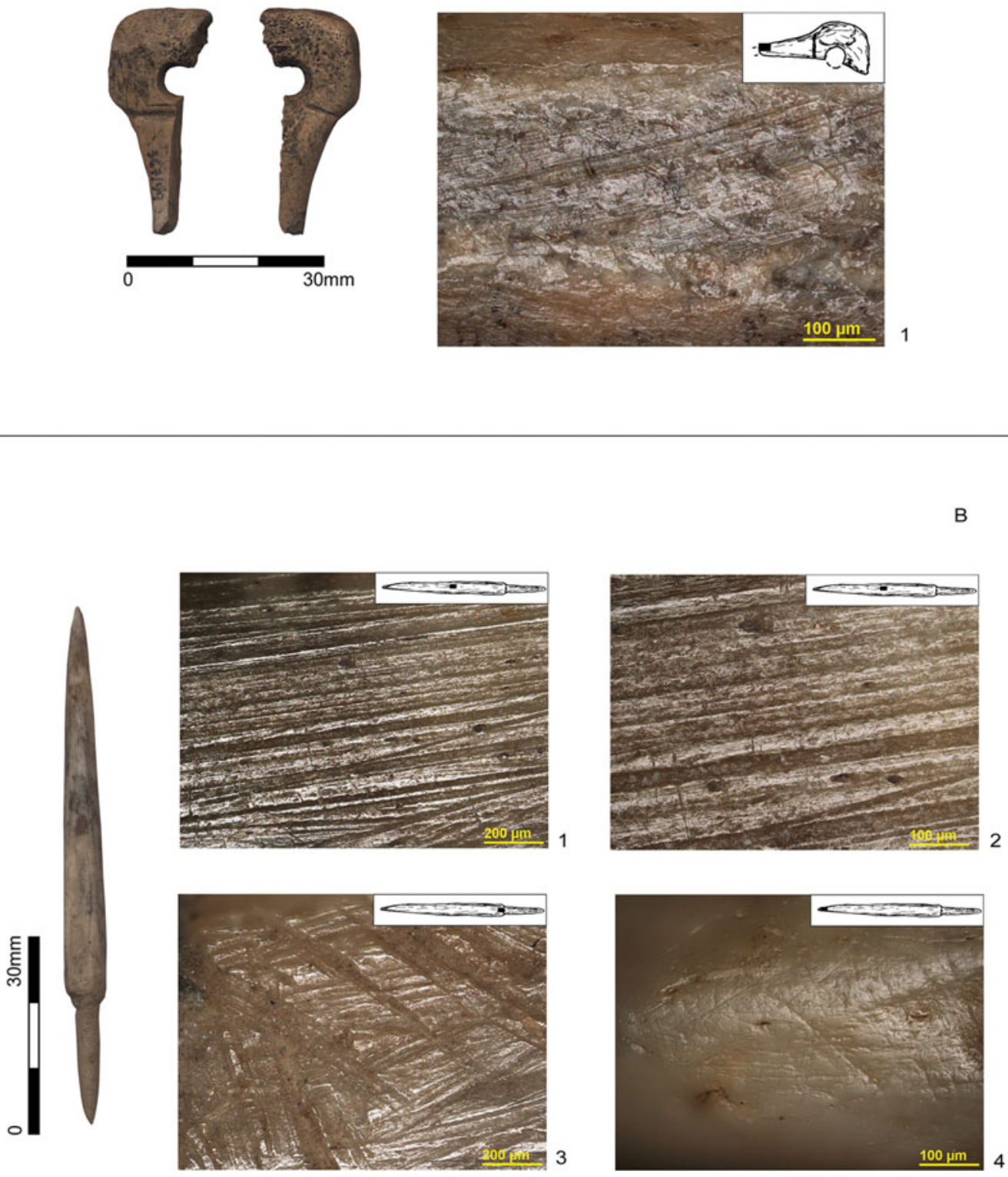

Figure 4. Wojkowice assemblage examples: A) traces of scraping with a metal knife on a bone pin; B) bone arrowhead with traces of: 1-2) scraping with a flint tool, 3) grinding on a sandstone pad, 4) use traces: tip polishing with impacts. All photographs by M. Diakowski.

Central European analogies to date, and are interpreted as bone- and antler-working pits used in the material-softening process. They yielded a small collection of 174 animal remains comprising raw material, half-products and waste. Fifty pieces of this assemblage were worked.

(C) Antiquity Publications Ltd, 2018 
Table 1. Manufacturing traces in the chronological contexts: Bronze Age (900-750 BC), Hallstatt C (750-550 BC) and Hallstatt D (550-400 BC). The numbers refer to the number of objects on which traces were observed.

\begin{tabular}{|c|c|c|c|c|c|c|c|c|c|}
\hline \multirow[b]{3}{*}{ Tool } & \multirow[b]{3}{*}{ Technique } & \multicolumn{4}{|c|}{ Grzybiany } & \multicolumn{3}{|c|}{ Wojkowice } & \multirow[t]{2}{*}{ Rusko } \\
\hline & & \multicolumn{7}{|c|}{ Chronological context } & \\
\hline & & $\mathrm{BA}$ & $\mathrm{HC}$ & $\mathrm{HC} / \mathrm{HD}$ & $?$ & BA & $\mathrm{EB} / \mathrm{HC}$ & $\mathrm{HC}$ & $\mathrm{HC}$ \\
\hline \multirow[t]{7}{*}{ Stone/flint } & Breaking & 3 & 12 & 1 & 1 & 12 & 16 & 5 & 12 \\
\hline & Knapping & 1 & - & - & 1 & - & 2 & - & - \\
\hline & Flexion breaking & 4 & 4 & 2 & 2 & - & 1 & - & 5 \\
\hline & splitting & 2 & 5 & - & 1 & 1 & 1 & - & 1 \\
\hline & Grinding & 6 & 6 & 2 & 5 & 12 & 26 & 6 & - \\
\hline & Scraping & 2 & 7 & - & 1 & 8 & 12 & 2 & - \\
\hline & Grooving & - & 1 & - & - & 1 & 1 & - & - \\
\hline \multirow[t]{7}{*}{ Metal } & Chopping & 5 & 15 & 4 & 3 & - & 1 & 4 & 34 \\
\hline & Sawing & 1 & 14 & 3 & 1 & 1 & 5 & - & 7 \\
\hline & Scraping & 4 & 1 & 3 & 3 & - & 1 & 1 & - \\
\hline & Whittling & 1 & 4 & 1 & 3 & - & - & 1 & 3 \\
\hline & Chiselling & 2 & - & - & 1 & - & - & - & - \\
\hline & Boring & 2 & 2 & - & - & 1 & 1 & - & - \\
\hline & $\begin{array}{l}\text { Ornamentation by } \\
\text { grooving }\end{array}$ & - & 1 & - & - & - & - & - & - \\
\hline
\end{tabular}

\section{Methods}

The first stage of analysis of the worked pieces involved macroscopic observations to identify natural $v$ s deliberately made traces. This was followed by microscopic analysis using a stereoscopic microscope (Olympus SZX9, up to 57× magnification) and a metallographic microscope (Nikon ECLIPSE LV100, 50-500× magnification).

\section{Production traces: tools and techniques}

The widest variety in terms of tools and working techniques was observed on the 75 objects from Grzybiany (Figure 2). Here, the processing of bone, antler and horn involved a variety of techniques, including the use of tools made of flint, stone or metal. The choice of tools clearly corresponds with a variety of techniques. For example, the assemblage has objects made only using stone or flint tools, objects made using only metal tools and several examples of the use of both stone and metal tools on a single object (Figure 3).

At Wojkowice, most objects were produced using very simple methods, such as breaking, grinding and whittling. Among traces made by stone and flint tools, there is evidence of breaking, knapping, flexion breaking, splitting, grinding, scraping and grooving (Figure 2). The use of metal tools, such as axes, knives or saws, left traces of chopping, sawing, scraping, whittling and boring (Figure 4).

The materials from Rusko exhibited a rather rough selection of traces, including chopping with a metal axe, sawing and whittling (Figure 2). The use of stone tools is attested 

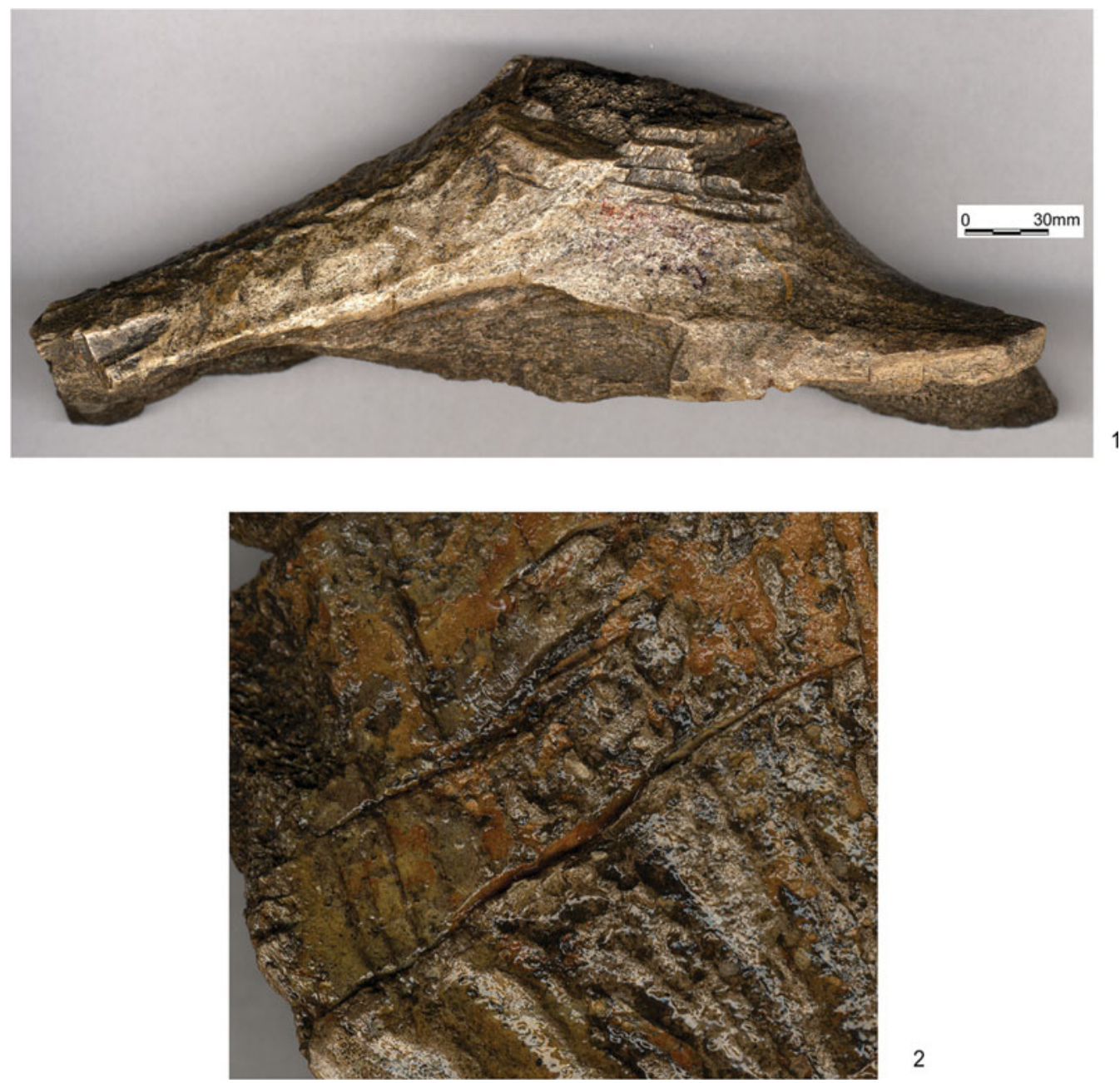

Figure 5. Rusko assemblage examples. Production traces with a use of metal tools: 1) chopping, 2) sawing. All photographs by M. Diakowski.

by flexion breaking, breaking and splitting. Most of the observed traces resulted from the initial division of the raw material, which correspond well with the context from which the artefacts came. Numerous and deep sawing traces observed in the cortex prove that antler was intensively softened (Figure 5).

\section{Traces, contexts and chronology}

When we compare variables such as chronology and the tools and techniques applied in bone and antler processing (Table 1), a wide range of tools (both in a technological and formal sense) are identified. It seems that metal tools, even in the Bronze Age, were used to a very limited degree, and that the Late Bronze Age communities were predominantly using stone tools. Despite abundant data on metal smelting and manufacturing, along (C) Antiquity Publications Ltd, 2018 
with bronze artefacts from south-west Poland, it seems that metal tools were rarely used in processing animal hard tissues. Interestingly, this situation changed in the Early Iron Age, which, in light of the presented data, seems to be a real breakthrough in the consistent use of metal tools. This period-understood as a time of intense external influences, but also characterised by local adaptation to innovations by the small communities in the area discussed-resulted in the wider use of metal tools in bone and antler processing. Some old techniques, such as scraping or chopping, did not change, but became more common after new tools were introduced. Other techniques involving the use of stone tools, such as grinding and breaking, were considered perfect and were never abandoned. Techniques using metal tools, such as sawing, chopping with a metal axe and whittling with a metal knife, became more common in the Early Iron Age.

Although the analysed sites date to the Late Bronze Age-which may suggest common use of metal tools in everyday activities - the research demonstrated the rather slow introduction of metal tools used for processing animal hard tissues.

\section{References}

Baron, J., M. Diakowski \& T. Stolarczyk. 2016. Bone and antler artefacts from a $8-5^{\text {th }}$-century BC settlement at Grzybiany, south-western Poland, in S. Vitezovic (ed.) Close to the bone: current studies in bone technologies: 28-47. Belgrade: Institute of Archaeology.
GralaK, T. 2010. Osadnictwo ludności kultury łużyckiej ze stanowiska Wojkowice 15, gm. Źórawina, pow. Wrocław. Archeologiczne Zeszyty Autostradowe 10: 7-252.

LASAK, I. 1995. Halsztackie pracownie obróbki poroży i kości w Rusku 34, gm. Strzegom. Studia Archeologiczne 26: 147-67. 